cillin; first by "bottle culture", then by deep fermentation.

It is a fascinating story of confidence in the ability to solve technical problems while being a realist in the use and need of capital resources and human skills. Initially through collaboration in the Therapeutic Research Corporation, but subsequently as agent for the Ministry of Supply, Jephcott sccured agrcement with the Mcrck. Squibb and Pfizer organizations in the USA which in the late 1940s enabled the manufacture of penicillin by deep fermentation to be preferred to the "tray" methods being explored by ICI and the small container methods preferred by others. He recognised the potential help of mycologists as well as chemists and the importance of selecting strains and producing mutants, the metabolism of which in media fortified by phenylacetic acid and hydroxyphenylacetic acid increased the yields many fold. New factories were developed both for manufacture of bulk antibiotics and also for sterile filling into containers for individual use on patients, both in this country and in several countries of the Commonwealth. The manufacture of penicillin was accompanied within a few years of its inception by the manufacture of streptomycin and there followed in the $1950 \mathrm{~s}$ the added bonus of production of vitamin $\mathbf{B}_{1:}$ from the fermentative processes of streptomyces species.

In the war years and subsequently, Excess Profits Tax limited the generation of financial resources for reinvestment and expansion. but with the abolition of EPT in the early 1950s the fortunes of the Glaxo organisation became transformed and deservedly so. For Jephcott had a fantastic intuitive sense of what was possible by industry; he could define the right course to take and rationalise his decision afterwards. He understood how to use wisely the expertise of others and never ceased to emphasise the possibilities of application of science. He could recognise and encourage capacity in applied chemistry and therein lay much of his success.

His example of hard work, devotion to duty, economical use of time and energy, fearless approach to challenge influenced many with whom he worked and dealt both in this country and overseas. The world became his parish and he travelled to all the continents developing local manufacturing units as necessary. He also served for five years as Chairman of the Department of Scientific and Industrial Research where his experience led him to advise Ministers of the different requirements for development of science and technology. Many in the research associations have good cause to be grateful for Jephcott's influence on their develop- ment, but so have the professions of chemistry and pharmacy.

$\mathrm{He}$ was President of the Royal Institute of Chemistry in 1953-1955, Chairman of the Association of British Chemical Manufacturers in 1947-1950, an Honorary Auditor for 40 years of the Pharmaceutical Society from whom he received their Charter Gold Medical in 1970 . He was Chairman of the Council of the School of Pharmacy, University of London, from its inception as a body independent of the Pharmaceutical Society in 1948 until 1969.

From his industrial successes he created several charitable trusts, but only in his latter years did he really learn to spend any money on himself. $\mathrm{He}$ was always generous to others but the hardships of his youth had taught him to waste nothing. Never a patient man he learnt of late to endure physical pain with fortitude and to the end he rejoiced in his friendships. He was a towering example of an upright man in every sense.

His services to the Ministry of Food were recognised by a Knighthood in 1946 and his transformation of the pharmaceutical and fine chemical industries by a Baronetcy in 1962. He left for others to write The Second Fifty Years of the organisation with which he became identified and to which he gave so much of his energy and life. It will be a fascinating story of the influence of intuitive judgment. recognition of the potential applications of science and a financial acumen that deserved success and achieved it.

Frank Hartley

\section{G. H. M. Lawrence}

Professor George Hill Mathewson Lawrence died at his home on Rhode Island in the United States on 11 June 1978. Born on 19 June 1910 at East Greenwich, Rhode Island, he studied at Rhode Island State College and Cornell University where he received his $\mathrm{PhD}$ in botany in 1939 .

He helped the eminent taxonomist, Liberty Hyde Bailey, in the revision of his Manual of Cultivated Plants (1949) while he was his assistant at the Bailey Hortorium at Cornell from 1945 to 1950 . Cornell appointed him a professor of botany in 1947 and four years later Lawrence became Director of the Bailey Hortorium. His Taxonomy of Vascular Plants (1951) which considered many aspects of the botanical sciences, especially phylogeny, was well received and was reissued in an abridged version in 1955.

In August 1960 he left Cornell to take up the post of Director of the Hunt Botanical Library (now the Hunt Institute for Botanical Documentation) at the Carnegie Institute of Technology (now the Carnegie-Mellon University) at Pittsburgh.

The Hunt Library was already renowned as an outstanding collection of choice books, drawings, prints and portraits in the fields of botany and horticulture, and it being the earnest wish of its founder, Mrs Rachel McMasters Miller Hunt, that it should not be dispersed, it was presented to the Carnegie Institute of Technology. Lawrence's assessment of Mrs Hunt as a person of 'great stamina, of amazing vigour and dynamism' could equally apply to himself. It was his energy, enthusiasm and vision that transformed this private library into an international centre for biobibliographical research. $\mathrm{He}$ shared Mrs Hunt's concern for exacting standards and quality and all the library's publications are distinguished by impeccable scholarship and elegant design. Lawrence's most ambitious project was the Bibliographia Huntiana, an exhaustive bibliography of botanical and horticultural books and periodical articles published during the period 1730 to 1840 . Although the Bibliographia Huntiana has not yet appeared the Botanico-PeriodicumHuntianum (1968) and the Master Book List (1972) are useful byproducts of the data already accumulated on magnetic tape.

Lawrence made substantial additions to the book stock, formed the nucleus of an archives collection and diversified the collection of botanical art with examples of the work of many contemporary artists. The acquisition, however, which gave him the greatest pleasure was Dr Birger Strandell's collection of books, periodicals and newspaper cuttings relating to Linnaeus. With Dr Strandell's assistance he undertook the compilation of an annotated catalogue of this immensely important collection and only a month before his death attended a conference in Sweden to report on its progress. Although he has not lived to see its publication, Professor Lawrence died as he would have wished, active and productive to the end.

Ray Desmond

\section{James Shields}

JAMES SiHFl.DS, who died on 20 June 1978, had achieved an international reputation for his contributions to the genetics of mental disorder and to twin research.

He was born on 21 November 1918. After two years at Oxford he was conscripted into the Royal Artillery. In 1945 he came back from five years in a prisonerof-war camp with a fine record for helping to maintain morale. He came to psychiatric genetics at the Maudsley Hospital in 1947, and later was seconded for ten 
years to the Medical Research Council's Unit. When that was closed in 1969 he returned to the Institute of Psychiatry, becoming Reader in Psychiatric Genetics.

During field work in 1954 he contracted polio, and thereafter was confined to a wheelchair. But with the courage that was typical of him he re-organised his life to surmount disablement and to continue research, lecturing, foreign visits and collaboration with a succession of visiting guest workers, virtually unimpaired.

He built up a register of consecutive cases of twins who were patients of the Maudsley Hospital, which has been, and it is hoped will continue to be the foundation of important field studies. The rigorous objectivity and self-critical understanding which he applied to twin studies has maintained it as a uniquely informative research tool after a period in which it was misunderstood and disparaged. His classic work on Monozygotic Twins Brought up Apart and Brought up Together was published in 1962 . It was based on the largest collection of separated twins so far made; and his analysis threw new light on the role of genetics in social environment and upbringing.

Shields collaborated in many papers with Irving Gottesman. Their work on Schizophrenia and Genetics, reported in 1972, was awarded the Hof heimer Prize. After the most critical examination of the genetical hypothesis, it was found conclusively that genetic factors specific to schizophrenia are involved in its aetiology.

Shields's wide range of genetical work also covered anxiety states, neuroses, homosexuality, alcoholism and adoption in relation to schizophrenia. His knowledge of the literature was encyclopaedic; his scholarship, intellectual distinction and passion for truth in a contentious field were recognised by the (rare) award of the honorary D.Med. of the University of Zurich in 1975.

Unassuming, uncomplaining and generous, he endeared himself to his colleagues. He had, through thick and thin, the loving support of his wife Elizabeth, sharing with her a gift and an enthusiasm for music.

Eliot Slater

\section{William Ellison}

William Ellison, Professor of Agriculture at the University College of Wales, Aberystwyth, died a few months before retirement, on 11 April 1978. aged 66.

He was a graduate of King's College, Newcastle, where, in 1934, he also gained a Ph.D. for work on the cytology of potatoes. In the same year he was appointed assistant lecturer in agricultural botany at Aberystwyth. Until the outbreak of war he continued his cytological work and col- laborated fruitfully with the staff of the Welsh Plant Breeding Station on the cytology of Avena species.

In 1939 his work and interests changed abruptly when he was appointed Chief Technical Adviser to the Montgomeryshire Welsh Agricultural Education Committee. This work, which continued throughout the war, was to bring him much renown, not only locally but nationally. $\mathrm{He}$ was instrumental in extending and putting into practice on a large scale the knowledge gained from experimental work of the 1920's and 30's, at the Welsh Plant Breeding Station and elsewhere, for the improvement of hill and marginal lands in Britain. His achievement confirmed not only his authority and expertise, but also his initiative and powers of leadership in this field.

When the war ended he became Professor of Agriculture at Aberystwyth and, from that time onward, he served his College with enormous dedication and the utmost loyalty. $\mathrm{He}$ served as Dean of the Faculty of Science and was Vice Principal from 1965 to 1967 . He was a member of the U.G.C. sub-committee on agriculture from 1965 to 1975 and President of Section $M$ of the British Association for the Advancement of Science in 1966. Apart from these 'academic' commitments Professor Ellison's influence was important in determining post - war agricultural policy towards the use and development of hill and marginal lands in the U.K., notably through his book on marginal land and as member of the N.E.R.C. Land Use Research Committee.

Professor Ellison was a staunch, even passionate advocate of the merits of university degree courses in agriculture. He would argue that the blend of science and technology, of art and craft, of economics and husbandry was a firm foundation for a broad, yet rigorous education. He would argue, also, that agriculture had as much to do with a way of life as with making a living. This is not surprising. He came from an ancient family of distinguished farmers, land agents and lawyers in the north country. He was proud not only of their professional achievements and enterprise but of the qualities of reliance, courtesy and public spirit which were part of their rural scene. Professor Ellison himself was well endowed with these qualities. He was unfailingly courteous, modest and unassuming and with an enormous capacity for making, and keeping, friends. These many friends will mourn his passing.

$\mathrm{He}$ is survived by two daughters. His wife died only four days before him, on 7 April 1978.

H. Rees

\section{J. G. Valatin}

John George Valatin, Professor of Theoretical Physics at Queen Mary College in the University of London, died on 19 April 1978, aged 60. Born in Budapest, John Valatin studied engineering at the Technical University there. Having obtained a doctorate for work on molecular spectra he worked for two years in industry before returning to the University at the end of the war as a lecturer in physics.

In 1947 he left Hungary to work with Louis de Broglie at the Institut Henri Poincaré. He was awarded the D.Sc. of the University of Paris for a thesis on the theory of the positron. In 1950 he went to the Niels Bohr Institute in Copenhagen, where he developed a covariant gauge independent formulation of quantum electrodynamics.

Two years later Valatin's interest in physics led him to the Mathematical Physics Department headed by Professor Peierls at Birmingham 'University. He spent thirteen years there and became a British citizen. In his early years in Birmingham he continued his studies in quantum electrodynamics doing pioneering work on the use of the point splitting technique to remove the divergence of that theory.

Following the fundamental work of Bardeen, Cooper and Schrieffer, and stimulated by the presence in Birmingham of J. R. Schrieffer as a young postdoctoral fellow, Valatin discovered in 1957 (independently of academician N. N. Bogolyubov) the canonical transformation which bears their names. This discovery gave greater insight into the nature of the ground state and of the elementary excitations in superconductivity. Over the next few years Valatin developed a generalization of the HartreeFock method designed to take account of the pairing forces which occur in superconductors. In collaboration with B. R. Motteison and D. J. Thouless he used this generalized Hartree-Fock method to discuss pairing forces in nuclei and their influence upon nuclear rotational states.

In 1965 he left Birmingham for a chair at Queen Mary College, London, where be established a theoretical group working both in the theory of elementary particles and in the theory of condensed matter. $\mathrm{He}$ established a research seminar that drew distinguished speakers from all branches of theoretical physics and which served as an eloquent witness to his belief that theoretical physics was a unified subject.

Although John Valatin's life was dominated by his interest in physics, he was a deeply committed Christian and was much concerned with the welfare of students, especially those from overseas.

$\mathrm{He}$ is survived by his wife and two sons. R. B. Jones W. Young 